7. Romanenko Juryj. Show-anization Retrieved from Retrieved from: http://ontoimago.spb.nl/article_139.html. [in Ukrainian].

8. Skrypka, Anna. (2010). Show-technology as a form of social communication: avtoref. dys. na zdobuttja pauk, stupenja kand. sociologhichnykh nauk : spec. 22.00.04. Kharkiv [in Ukrainian].

9. Ukraine at the Eurovision Song Contest. Retrieved: https://uk.wikipedia.org/wiki. [in Ukrainian].

10. Fan-site of the show "X-Factor" in Ukraine. Retrieved from: http://xfactor.kiev.ua. [in Ukrainian].

11. X-factor. Rezhym dostupa: https://uk.wikipedia.org/wiki/X. [in Ukrainian].

12. Khabarov, A. (2010). A scandal around the "X-Factor":"no!"to falsifications. 2010. № 47 [in Ukrainian].

13. How is the life of the brightest participants in the Voice of the country. Retrieved from: https://1plus1.ua/golos-krainy/novyny/ak-sklalasa-dola-najjaskravishih-ucasnikiv-golosu-kraini [in Ukrainian].

Стаття надійшла до редакиії 11.02.2019 p.

УДК 785.6:787.61

Тущенко Михайло Михайлович, старший викладач інституту мистецтв Київського університету імені Бориса Грінченка 0000-0002-4315-3651

tuschenko_m@ukr.net

\title{
М. СТЕЦЮН «ІСПАНСЬКИЙ КОНЦЕРТ» ДЛЯ ГІТАРИ З ОРКЕСТРОМ: ДО ПИТАННЯ СТВОРЕННЯ НАЦІОНАЛЬНОГО РЕПЕРТУАРУ В ГАЛУЗІ ГІТАРНОГО МИСТЕЦТВА
}

\begin{abstract}
Мета роботи - детальний аналіз «Іспанського концерту» для гітари із симфонічним оркестром М.Стецюна, розкриття його інтонаційної й композиційної єдності, особливостей творчого методу композитора. Особливу увагу дослідник приділяє стилістиці твору задля вияву поєднання рис двох національних шкіл української та іспанської (фламенко). Методом дослідження було обрано стилістичний, композиційний та інтонаційний аналіз твору. Актуальність роботи полягає в її відповідності сучасним потребам національного мистецтва та освіти, а саме в появі досліджень новітнього гітарного репертуару 3 метою популяризації творчості сучасних українських композиторів. Наукова новизна: дана праця є першою спробою детального аналізу «Іспанського концерту» для гітари із симфонічним оркестром М. Стецюна в українській гітаристиці. Висновки. Відтак, можна впевнено стверджувати, що остання чверть ХХ століття стала новітнім періодом розвитку національного гітарного мистецтва, а „Іспанський концерт” Миколи Стецюна $є$ одним 3 яскравих зразків сучасного українського концерту для гітари з оркестром, в якому пошук альтернативних канонічних рішень стає найоптимальнішим засобом вияву індивідуальної позиції митця, полем художнього експерименту. Стилістика твору поєднує риси двох національних шкіл, що дає можливість розкрити риси єдності музичних культур на різних рівнях: драматургічному, композиційному, інтонаційному. Авторське бачення національної характерності образної сфери цього твору реалізується через сучасну музичну мову. Композитору вдалось використати виразові і технічні можливості гітари, прийоми регістрово-тембрової контрастності, кантиленну природу інструмента.

Ключові слова: «Іспанський концерт» М. Стецюна, Концерт для гітари 3 симфонічним оркестром, Гітарне мистецтво, Національний репертуар, Творчий метод композитора, Гітара в Україні, Інструментальне виконавство.
\end{abstract}

Тущенко Михаил Михайлович, старший преподаватель института искусств Киевского университета имени Бориса Гринченко

Н. Стецюн „Испанский концерт” для гитары с оркестром: к вопросу создания национального репертуара в области гитарного искусства

Цель работы - детальный анализ «Испанского концерта» для гитары с симфоническим оркестром Н. Стецюна, раскрытие его интонационного и композиционного единства, особенностей творческого метода композитора. Особое внимание исследователь уделяет стилистике произведения для проявления сочетание черт двух национальных школ - украинской и испанской (фламенко). Методом исследования был выбран стилистический, композиционный и интонационный анализ произведения. Актуальность работы заключается в ее соответствии современным потребностям национального искусства и образования, а именно в появлении исследований новейшего гитарного репертуара с целью популяризации творчества современных украинских композиторов. Научная новизна: данная работа является первой попыткой детального анализа «Испанского концерта» для гитары с симфоническим оркестром Н. Стецюна в украинской гитаристике. Выводы. Следовательно, можно уверенно утверждать, что последняя четверть XX века стала новейшим периодом 
развития национального гитарного искусства, а "Испанский концерт" Николая Стецюна является одним из ярких образцов современного украинского концерта для гитары с оркестром, в котором поиск альтернативных канонических решений становится оптимальным средством проявления индивидуальной позиции художника, полем художественного эксперимента. Данные проведенного анализа позволяют сделать вывод, что стилистика произведения объединяет черты двух национальных школ, дает возможность раскрыть черты единства музыкальных культур на разных уровнях: драматургическом, композиционном, интонационном. Подытоживая все сказанное, отметим, что авторское видение национальной характерности образной сферы этого произведения реализуется через современный музыкальный язык. Композитору удалось использовать выразительные и технические возможности гитары, приемы регистрово-тембровой контрастности, кантиленной природы инструмента.

Ключевые слова: «Испанский концерт» Н. Стецюна, Концерт для гитары с симфоническим оркестром, Гитарное искусство, Национальный репертуар, Творческий метод композитора, Гитара в Украине, Инструментальное исполнительство.

\section{Tushchenko Mykhaylo, Senior Lecturer, Institute of Arts Borys Grinchenko Kyiv University \\ N. Stetsyun "Spanish concert" for guitar with orchestra: to the question of creation of a national repertoire in the field of guitar art \\ The purpose of the article is a detailed analysis of the "Spanish concert" for guitar and Nikolay Stetsyun's} Symphony Orchestra, the disclosure of his intonational and compositional unity and the features of the composer's creative method. The researcher pays particular attention to the work's stylistics in order to show the combination of the two national schools' traits - Ukrainian and Spanish (flamenco). The stylistic, composite and intonational analysis of the work was chosen as the method of the research. The relevance of the work lies in its compliance with the contemporary needs of national art and education, namely, the emergence of studies of the newest guitar repertoire in order to popularize the work of modern Ukrainian composers. Scientific novelty: this work is the first attempt of a detailed analysis of the "Spanish Concert" for a guitar with the N. Stetsun's Symphony Orchestra in Ukrainian guitar. Conclusions. Therefore, we can confidently assert that the last quarter of the twentieth century was the newest period of development of the national guitar art, and the "Spanish Concerto" by Nikolay Stetsyun is one of the brightest examples of the modern Ukrainian concert for guitar and orchestra, in which the search for alternative canonical solutions becomes the optimal means for the manifestation of individual position of the artist, the field of artistic experiment. The analyzed data allows us to conclude that the style of the work combines the features of two national schools, which makes it possible to reveal the features of the unity of musical cultures at different levels: dramaturgical, compositional, intonational. Summarizing all the above, we can note that the author's vision of the national specificity of the figurative sphere of this work is realized through the modern musical language. The composer managed to use the expressive and technical capabilities of the guitar, the methods of the register-timbre contrast, the melodic nature of the instrument.

Key words: "Spanish Concert" N. Stetsyun, Concert for guitar with a symphonic orchestra, Guitar art, National repertoire, Creative method of the composer, Guitar in Ukraine, instrumental performances.

Актуальність теми дослідження. Сучасна музична наука охоплює широкий спектр проблематики, пов'язаної, зокрема, i 3 розвитком теорії та історії виконавського мистецтва. Різноманітність материалу для практичної діяльності тягне за собою необхідність його теоретичного осмислення.

Актуальність роботи полягає в іiі відповідності сучасним потребам національного мистецтва та освіти, а саме в появі досліджень новітнього гітарного репертуару з метою популяризації творчості сучасних українських композиторів.

Аналіз досліджень і публікацій. Положення роботи базуються на взаємодії історичного і теоретичного музикознавства. Основні праці систематизовані за такими предметними напрямками:

- теорія і історія світової музики (М.Арановський [1]; В.Манилов [2]; М.Тараканов [7]; Ю.Холопов [8]);

- творчість Миколи Стецюна (А.Муха [5]; М.Стецюн [6]).

Мета дослідження: детальний аналіз «Іспанського концерту» для гітари із симфонічним оркестром М. Стецюна, розкриття його інтонаційної й композиційної єдності, особливостей творчого методу композитора.

Виклад основного матеріалу. Мистецтво гри на гітарі існує у різних варіантах виконавства аматорському, камерному, концертному. Маючи давні музичні традиції, воно акумулює найкращі досягнення минулого, постійно оновлюється і збагачується завдяки розвитку національних шкіл, де асимілювався цей музичний інструмент.

В Україні гітара з'явилась в музичному побуті на межі XVII-XVIII ст. спочатку як інструмент сольного музикування, а згодом набула широкого розповсюдження завдяки принципам гри, які нагадували гру на національних щипкових інструментах. 
Останнє двадцятиріччя - новітній період розвитку національного гітарного мистецтва. Ця тенденція намітилась значно раніше - наприкінці 60-х років минулого століття, коли до створення національного гітарного репертуару звернулись такі видатні композитори як Л. Грабовський, Л. Колодуб, Є. Милка. Однак саме сьогодні пошук альтернативних до канонічних рішень стає найоптимальнішим засобом вияву індивідуальної позиції митця, полем художнього експерименту.

Але необхідно зауважити, що при наявності достатньо широкого та різноманітного репертуару для гітари, створеного українськими композиторами, це, найчастіше, - п’єси різного характеру, етюди, рідше - сонати. Щодо творів великої форми - концертів для гітари з оркестром, то в цій галузі можливо привести значно меншу кількість прикладів (концерти Я. Лапинського, П. Палухіна). Одним зі зразків сучасного українського концерту для гітари з оркестром $\epsilon$ „Іспанський концерт" Миколи Стецюна, аналіз якого є метою статті.

Композитор працює в різних жанрах. В його творчому доробку є твори для симфонічного та народного оркестрів, мюзикли, дитяча опера, камерно - інструментальні твори (ансамблі та квартети для струнних) та твори для окремих інструментів, серед яких - для 6-ти струнної гітари - 4 п'єси (1974), „Іспанський концерт” для гітари з симфонічним оркестром (1997) та „Варіації на тему Кореллі” (2000p.)

„Іспанський концерт” (прем’єра відбулася у Харківському оперному театрі; виконавці симфонічний оркестр Харківської філармонії, диригент - лауреат всеукраїнських і міжнародних конкурсів, диригент Національної телерадіокомпанії України Вікторія Жадько, соліст - лауреат міжнародних конкурсів, Заслужений артист України, професор Харківського університету мистецтв Володимир Доценко, якому і був присвячений твір) демонструє артистизм, багатство емоційного змісту, виваженість архітектонічних рішень.

Свій задум автор втілює в порівняно нетиповій для жанру двочастинній формі. Це можна пояснити небажанням композитора звертатися до формотворчих прийомів, вже канонізованих у процесі еволюції концертного жанру, „коли традиційна тричастинна схема „швидко - повільно швидко" хоч і зберегла своє значення, але також стала лише однією з багатьох можливих".[7, 147]

Солюючий інструмент та оркестр знаходяться в постійному діалозі - змаганні. I все ж тип конвертування можна визначити як домінантно-солюючий. Саме гітара інспірує емоційну напругу в різних зонах форми, енергійно репрезентує основний тематичний матеріал, визначає перспективи його подальшого розвитку. Партія гітари постає в усьому багатстві своїх експресивних можливостей.

Концерт представляє той тип художнього мислення, для якого характерне мозаїчне втілення життєвих колізій, у зв'язку з чим образна сфера твору доволі різноманітна та калейдоскопічна. Вона обіймає пристрасну рецитацію 3 ухилом у драматизовану епічність, задушевну ліричність, філософський роздум, вогняний танок. Усе це підвладне стихії руху - цілеспрямованого, твердого й несхибного у прагненні до кінцевої мети, сповненого динаміки поривання.

Структурні „блоки”-розділи „Іспанського концерту” контрастно репрезентують різні емоційні „ситуації”. Намагаючись подати кожен образ у динамічній перспективі, автор підкреслює контрастність у межах кожної частини: образи дійові, 3 різним смисловим навантаженням, чергуються 3 наспівно-ліричними, психологічні, філософські - 3 танцювальними, орнаментальноспоглядальними. Драматургія твору засновується на співставленні контрастних за психологічним та темброво-регістровим забарвленням образів. М. Стецюн намагається не залишатися в сфері якогось одного психологічного стану чи тембру-кольору, а постійно змінює їх, як у кіномонтажі. тематизму.

Велику увагу композитор приділяє інтонаційній яскравості та філігранній вирізьбленності

Стилістика концерту об’єднала в собі риси двох національних шкіл - української та іспанської (фламенко). Використання національних та інонаціональних традицій розкриває риси єдності згаданих музичних культур на різних рівнях - драматургічному, композиційному, інтонаційному. У Концерті відтворений дух народного, найтонші елементи національного стилю, без звертання до цитування фольклорних зразків.

Цілісність твору, органічний розвиток матеріалу досягається завдяки використанню кількох основних мелодичних поспівок та зворотів, на трансформуванні яких побудована переважна більшість фігураційного матеріалу в концерті. Інтонаційне „зерно”, з якого виростає тематичний матеріал твору, закладено у вступі, яким відкривається I частина ( $a$-moll, сонатна форма зі вступом). Головні принципи художнього рішення вступу - рапсодичність та монологізм.

Може здатися дивним, що в концертному жанрі, діалогічному за своєю природою, розвиваються монологічні форми; монологізм стає специфічною категорією інструменталізму. Але це відповідає загальній тенденції до інтелектуалізації художніх концепцій, яка обумовила розвиток 
різних жанрів на сучасному етапі. Так в концертному жанрі зазнає перетворення одна 3 найстабільніших якостей симфонічного мислення - концепційність. А у розв'язанні основної проблеми симфонізму - створенні цілісної концепції людини - проявляються тенденції, визначені М. Арановським як „стиснення системи опозиції до однієї (діяння - медитація)”.[1, 46]

Власне, вступ - це „епіграф” до концерту, який втілює в собі головну тематичну ідею невеликий чотиритактовий мотив, де закладений лейт-інтонаційний комплекс твору - секунда та чиста кварта. Вони стануть первинною будівельною ланкою, цементуючою весь концерт. У монолозі соліста своєрідно перетворюється одна з головних прикмет концерту - інструментальна віртуозність, втілена в майстерності мовної декламації на інструменті.

В останніх тактах вступу „розповідь” соліста стає більш енергійною, відбувається активізація руху. Декламація переходить у закличні інтонації, де основну роль відіграє тріоль шістнадцятими вступає в силу традиція так званого „халео” (у мистецтві фламенко це вигуки схвалення, які підіймають ентузіазм публіки), з якого починається вистава.

Світлий, зворушливий душевний смуток визначає емоційний настрій початку основного розділу. В основу головної партії (ц. 1)* покладений двотактовий мотив 3 наступним варіантним розвитком. За жанровими витоками ГП близька до української ліричної пісенності. На відміну від монологічного вступу, експозиція послідовно витримує діалогічність як провідний принцип розгортання образів.

Різка зміна темпу (Allegretto), розміру (6/8) та тональності (D-dur) знаменує появу сполучної партії, яка виконує функцію переключення в нову образну сферу - танцювальності, що стане домінуючою в другій частині концерту.

Побічна партія (ц. $5, D$-dur) має синкопований ритм, звучить впевнено, динамічно. У сфері ПП починається ускладнення гармонічної мови.

Розробка складається з трьох розділів, у яких крім розвитку інтонацій основних тем частини поступово „визріває” провідна теза, закладена у вступі. Тут особливо яскраво виявляється майстерність композитора щодо секвентно-варіантного розвитку матеріалу. Гітара не протиставляється оркестрові, а немов зливається з ним в єдиному звучанні.

В репризі композитор не переосмислює характер тематичного матеріалу та прийоми його викладу. Загальний розвиток направлено до коди (ц. 27), де на гребені кульмінаційного руху вперше у сформованому вигляді проходить тема - теза. В цьому проведенні, як і в першій хвилі становлення теми, композитор звертається до поліритмії, характерної в традиції фламенко - коли соліст співає в подвійному розмірі, а йому акомпанують в потрійному.

Останні такти I частини - свого роду коментар до тези. Соліст ще раз проводить тему головної партії, що сприймається як авторська післямова, спогади про те, що відбулося.

II частина (Allegretto, G-dur, трьох-n'ятичастинна концентрична форма) переносить слухача в атмосферу граційних танцювальних ритмів та поспівок. Ледь помітні джазові впливи збагачують колористичні можливості партитури. Суттєву роль відіграє ритм, якому належить роль одного 3 чинників розвитку матеріалу.

Ідея синтезу тематизму частин матеріалізується вже в проведені першої теми (А; затакт до ц.1). Перед появою другої теми (т. В, 4 такти до ц. 8) розташована зв'язка-перехід (ц. 6), яка заснована на інтонаціях основної теми.

Чотиритактовий вступ, що вводить у середній розділ частини (т. C, as-moll, ц. 10), заснований на додатковому перехрещуванні ритмів (литаври та palmas sordas - хлопки у долоні). Середній розділ фіналу вносить контраст в образну сферу, який створюється різницею жанровості та орієнтації на загальностилістичне коріння. На зміну об'єктивним картинам народного свята приходить суб'єктивізм. Танцювальність зникає, образний зміст теми асоціюється з експресивною розповіддю про глибоке, складне почуття. Реприза т. В (As-dur, 2 т. до ц. 12) дзеркальна. Матеріал зв'язки переходу підводить до останнього розділу частини - коди. Напруження зростає до останніх тактів твору, коли соліст могутніми акордами на $s f$ стверджує основну тональність всупереч низхідній хроматичній гамі, що проходить в партіях низьких дерев'яних та струнних. Лише в заключних тактах концерту композитор остаточно об’єднує партії соліста та оркестру.

Наукова новизна. Представлена в роботі концепція є першим спеціальним дослідженням, присвяченим детальному аналізу «Іспанського концерту» для гітари із симфонічним оркестром М. Стецюна в українській гітаристиці. Вперше всебічно проаналізовані провідні компоненти музичної мови М.Стецюна з урахуванням жанрово-виконавської специфіки твору, тематичного мислення, особливостей стилістики. 
Висновки. Таким чином, авторське бачення національної характерності образної сфери цього твору реалізується через сучасну музичну мову.

Провідними компонентами музичної мови композитора, які розкриваються в концерті та характеризують його $є$ : вільне використання всього діатоніко - хроматичного звукоряду з визначеним тяжінням до бімодальності; різноманітність ритмічних формул, використання подвійного, потрійного розміру та комбінації обох, додаткових перехрещувань ритмів; відповідно до традицій фламенко та українського епосу часте використання мелізматики, висхідних та низхідних форшлагів для акцентування окремих нот; прагнення до тембрового живопису, а також утворення змістовно конструктивної єдності цілого завдяки майстерному використанню тематичних модифікацій образів на основі варіантної техніки.

М. Стецюн вдало використовує виразові і технічні можливості гітари, прийоми регістровотембрової контрастності, кантиленну природу інструмента.

„Іспанський концерт” М. Стецюна став цікавим зразком концерту для гітари 3 оркестром i вагомим внеском у розвиток національного гітарного репертуару.

\section{תimepamypa}

1. Арановский М.Г. Симфонические искания. Исследовательские очерки. Ленинград : Советский композитор, 1979. $286 \mathrm{c}$.

2. Манилов В.А. Фламенко. Гитаристъ. 2003. № 147 (с момента возобновления издания). С. 22-25.

3. Музыкальная энциклопедия: в 6 т. / главный редактор Келдыш Ю.В. М.: Сов. энциклопедия, 1973. T. 1. C. $988-989$.

4. Музыкальная энциклопедия: в 6 т. / главный редактор Келдыш Ю.В., М. : Советская энциклопедия, 1981. T. 5. C. $838-845$. автора).

5. Муха А.І. Композитори України та української діаспори: довідник. К.: Муз. Україна, 2004. 289 с.

6. Стецюн Н.Г. Испанский концерт для гитары с оркестром : рукопись партитуры (из личного архива

7. Тараканов М.Е. Симфония и инструментальный концерт в русской советской музыке (60 - 70-е годы). Пути развития: очерки. М.: Советский композитор, 1988. 271 с.

8. Холопов Ю.Н. Гармония: Теоретический курс : учебник. СПб.: Издательство «Лань», 2003. 544 с.

\section{References}

1. Aranovskiy, M.G. (1979). Symphonic quest. Research essays. Leningrad: Soviet Composer [in Russian].

2. Manilov, V.A. (2003). Flamenco. Guitarist, 147 (since the resumption of publication), 22-25 [in Russian].

3. Keldysh, Yu.V. (Eds.). (1973). Musical encyclopedia: 6 t. M.: Soviet Encyclopedia [in Russian].

4. Keldysh, Yu.V. (Eds.). (1981). Musical encyclopedia: 6 t. M.: Soviet Encyclopedia [in Russian]. Ukrainian].

5. Mukha, A.I. (2004). Composers of Ukraine and the Ukrainian Diaspora. Kyiv: Musical Ukraine [in

6. Stetsyun, N.G. Spanish concert for guitar and orchestra (from the author's personal archive) [in Russian].

7. Tarakanov, M.E. (1988). Symphony and instrumental concert in Russian Soviet music (60 - 70 years). Ways of development. M.: Soviet Composer [in Russian]. Russian].

8. Kholopov, Yu.N. (2003). Harmony: Theoretical course: textbook. - SPb.: Lan publishing house [in

Стаття надійшла до редакиії 18.01.2019 p. 